\title{
A STUDY ON EVOLUTION AND DEVELOPMENT OF URBAN REGENERATION WITH EMPHASIS ON THE CULTURAL APPROACH
}

\author{
Ali Sharghi ${ }^{1}$, Yousef Jahanzamin ${ }^{2}$, Abdolhamid Ghanbaran ${ }^{3}$, Shahrzad Jahanzamin*4 \\ ${ }^{1}$ Assistant Professor, Department of Architecture, Shahid Rajaee Teacher Training University \\ ${ }^{2}$ Assistant Professor, Department of Architecture, University of Mohaghegh Ardabili \\ ${ }^{3}$ Assistant Professor, Department of Architecture, Shahid Rajaee Teacher Training University \\ ${ }^{* 4}$ Master Student, Urban Design, Shahid Rajaee Teacher Training University
}

\begin{abstract}
City is the result of historical and natural evolution of human biological communities. Following the rapid developments of modern times, entering transition step, and changing living structures from traditional to modern that result in new form of social and economic relations in society and changing cities totally; there were parts of urban context, specially historical and central core of cities context, that failed to coordinate with the ongoing changes and because of physical- operational mismatch with new conditions their inhabitant became unkind to them and so Inevitably and following the lack of necessary infrastructures forecast for joining to the dynamic and integrated urban body they made current worn-out urban parts. Today one of the most important challenges about the historical context is dealing with their physical exhaustion and adopting intervention methods that this part has experienced different methods according to space and time from past to now. For increasing historical context coordination with modern needs, one of the protective- restoration intervention methods that attracted the attention of many urban planners is urban regeneration. Urban regeneration has different aspects and has changed and evolved by the time passage. One of the most important aspects is regeneration based on cultural principle and foundations. These days this aspect has attracted the attention of citizens and officials because of meeting the diverse needs and strengthening the sense of identity of the citizens of a region. The research that was carried out using documents and library studies tries to explain the protective and restoration intervention methods, documents and resolutions related to them, urban regeneration procedure, principles and general strategies of regeneration, and finally emphasis on cultural regeneration as an effective approach, and present overall solution and analyze examples of this intervention recipients.
\end{abstract}

Keywords: Regeneration - Public Spaces - Cultural Approach

\section{INTRODUCTION}

City is a living body that parts of it gradually experience exhaustion and destruction because of natural causes. Time passage and changes that occur in requirements and consequently on needs and method of meeting that needs by city residences, changes urban spaces. These changes affects different aspects of the city (whether physical and non-physical or their inter-relations) and time foot print remains on the city's appearance. In fact the city is the product of various historical periods and special relationships of social, cultural, anthropologic, geographic and economic aspects. However, the most important criteria which affects urban body and changes its identity is the boundary between past and present of the city and the separation of the two periods. appearence of the cities has always continuously changed, however, at some periods, the separation between past and present has been more significant. In Iran, with advent of modernism at the late Qajar Era, changing the urban face has initiated and reach more increasing growth in the recent years by development of consumerism and mechanical life. With the emerging transformations, it was necessary to keep a balance between physical structures of historical regions of the city and modern life style in order to keep the city qualities. The researchers proposed measures to create this interaction in the city especially in the worn-out textures. In Iran, it has been executed through local or temporary measures in the form of reparation and keeping up the appearances of valuable urban textures and historical spots (such as the measures taken in istorical cities like Isfahan, Yazd, Kashan and etc.) or total reconstruction of the texture with no valuable 
historical spots without considering the social issues, population identity and history of habitation in these regions.

In normal situation, reconstruction of urban textures is a process which is performed by inhabitants to respond the changes of society's performance and needs. But, most of the times it has not been performed in historical regions by a sound and suitable approach, however, to prevent the demolition of texture and definition of new use for repaired structures, other measures can also be investigated. "Regeneration" is one of these measures that in recent years has found its popularity and is able to restore past identity and nature in today's texture and body.

\section{METHODOLOGY}

The present research has been done through a literature review and the documents studies; first, the concept of regeneration, its evolution, history, the published documents and resolutions related to regeneration in the past years and its principles and approaches hace been studied, then according to main approach of the study, importance and necessity of cultural regeneration, its evolution history and different aspects of its implementation and the local and overseas examples have been investigated and finally a summary has been presented.

\section{Theory}

In this section, regeneration concept from various point of views has been explained, transition and evolution history of regeneration and methods, regeneration plans and policies in historical- cultural textures have been investigated, then resolutions and conventions related to the topic, national documents about regeneration of worn out textures and main and new approaches mentioned in the regeneration principles and process and evolution of regeneration have been studied.

\section{Regeneration Concept}

The worn out textures, is the textures that formed during long period of times and now are surrounded by today's technology. Although these regions had logical and hierarchical functions in the past times, today they have structural and functional deficiencies and is unable to provide the inhabitants needs (Habibi et. al, 1386).

Urban regeneration seeks to find solutions for urban decay through improvement of deprived and deteriorating regions. This approach not only looks for revitalization of abandoned regions but also deals with broad topics such as competitive economy and quality of life especially for the people living in poor neighborhoods. "Regeneration" is form the verb "regenerate" means revitalization, revival and it also means natural reproduction of a part of a living mechanism that is subject to degradation (Roberts, 2000).

In general it can be said that urban regeneration is a process of creating new urban spaces with preserving the main spatial characteristics (physical and functionally). Urban regeneration includes a comprehensive and integrated view and a set of measures that help to resolve urban issues, so that a sustainable improvement is obtained in economic, physical, social and environmental situation of the texture that has undergone the change (Roberts, 2000).

\section{Evolution of Urban Regeneration}

Regeneration take various driving forces and documents as the basis or objective, in other words it create different development opportunities using various approaches. Therefore, there has been a wide range of regeneration techniques (Lotfi, 1390). Due to continuous history with over a century in urban improvement and regeneration, the time period from industrial revolution to the present century has drew attention of the architects and urban planners more than other periods. Investigation of this period and a brief review of the lesson learnt by urban regeneration evolution seems necessary.

1- $\quad 19^{\text {th }}$ century: Baron Hosman measures and UK regulations and plans to protect old textures

2- $\quad$ Early $20^{\text {th }}$ century: extensive reconstruction of the destruction caused by the world war. Athens Congress with preservation ideas 
3- $\quad$ 1950s: physical reparation and urban regeneration from world war II

4- 1960s: Regeneration, functional restoration and empowerment of the texture (social and economic issues).

5- 1970s: physical renovation plans considering political, social and economic issues.

6- $\quad$ 1980s: redevelopment including collaborative reconstruction, improvement and regeneration.

7- 1990s: preserving the history without neglecting historic identities and creating an identity according to the present needs.

8- Third millennium: urban regeneration and emphasis on sustainability in all aspects with collaboration of local communities.

\section{The Evolution of Aspects, Programs and Policies of Protection and Regeneration in Historical-Cultural Texture}

Evolutions of 1970's can be considered as the first steps of making common area between protection and development. In England the cities of Beth, Chicester and York are examples of the first cities executing urban restoration programs which consider protection subject as driver for development and regeneration in historical cities planning (Habibi \& maqsudi, 2007). Despite the differences, all of these plans are comprehensive plans and are supporter of balancing between protection of city historical values and aspects and city development and modernization (Pendelbery, 2005).

In Italy the plans of main cities, Gubbio, and Vicenza were as the first experiences and then Urbino, Bologna and Ferrara were the other experiences of this era that consider the historical centers in an integrated approach, but the focus was on historical buildings (Jokilehto, 2007).

Also, this period was the initiator of paying attention to the social value of heritage and underlying agent of values protection attitude from building scale to texture scale was commenced from Amsterdam resolution in 1975. Such measures and programs were representative of convergence between protection and regeneration policies or in other words development for the first time (Ashworth, $1991 \&$ Pendelbery, 2009). Therefor the 70 's can be considered as a specific emphasis on social values of heritage, the 80 's can be considered as emphasis potential economies of heritage and the 90's can be considered as a reaction to the created criticism to the redevelopment and Real Estate development plans of 80's along with making endeavors on historical places protection with emphasis on integration subject in protection area (Pendelbery, 2009). Since the late twentieth century tendency to reuse historical building that was started from past decades, change the direction of protection movement toward profitable use (economical) from historical buildings (Larkham, 1999).

\section{Regeneration Properties and Policies Based on Resolutions, Conventions and International and National Published Documents.}

From the late 1970's "integrated protection and regeneration" approaches was presented as dominant approach in historical- cultural environments and communities, people and institutes in local, national and international scale pay attention to it and develop it. Different organizations activities, executing national and international conferences and resolutions, recommendations and instructions make new space to guide this approach (Jokilehto, 1998)

Examples of regeneration documents are: Maastricht Treaty (1992), New Zealand ICOMOS charter (1993), Columbia- Sri Lanka Instruction (1993), Osaka Statement (1993), Fas Charter (1993), Nara meeting document (1994), Bergen resolution (1995), Sanantony Statement (1996), Sofia Charter (1996), Stockholm gathering resolution (1998), Melbourne Declaration (1998), Santiago De Compostila Declaration (1999), Bura Charter (1979 approved), and Corrigendum and reconsiderations documents (1981,1988 and 1999), ICOMOS 12'th general meeting in Mexico (1999), Mexico City Declaration (1999), Krakow Charter (2000), Quebec Declaration (2001), Budapest Statement (2002), Kazan Statement (2002), ICOMOS 14'th general meeting in Zimbabwe Charter (2003), Hoy An Statement (2003), protection of Islamic nations Urban heritage Charter 
(2003), and also resolutions of European council international symposiums in 2002 to 2007 and Charter of ICOMOS 16'th meeting in Quebec (2008). These documents have presented new approaches relating to the "integrated protection and regeneration" policies and are demanding organizations, communities and professional institutions to comprehensively protect these activities and agreed policies of thought owners. The main authority for these documents regulation are "United Nations Educational, Scientific and Cultural Organization (UNESCO)", "International Council on Monuments and Sites (ICOMOS)", "International Organization Of Historical Cities dependent on ICOMOS", "Getty Center in USA", "English Heritage Trust" and European council with establishment of "European council of historical cities and regions" that are working on widespread protection knowledge promotion (Hanachi And Fadayinezhad, 1390).

In Iran professional meetings, congress, conferences relevant to protection of historical- cultural wealth were held at first by foreign researchers like "Ernest Hertesfeld, Phylips Akerman And Arthur Yup" and then by formation of The National Monuments Council with government support at beginning of current century (Hanachi Et al. 2007). The third group of these conferences that usually contain statements and resolutions were begun at the late of 1960's and continue by now. Some of the last ones of these conferences are conference of Revitalization of wealthy historical textures of Yazd in 2008 and set of conferences on Improvement and Renovation of Mashhad Worn-out urban texture in 2008 November and 2010 May that were held by Provincial Cultural Heritage Organization and Provincial corporations od Development and Improvement and by support of ministry of housing. But despite the efforts, the influence of Intellectual currents on decision making process, policies and planning were very little. Investigation of charters, declarations and documents published in the last two decades shows how the word of protection that generally focused on protection and promotion of the historical structures, is being used in concept of change of historical environments management in recent decades (English Heritage, 2008). How conservation approach that was started from the beginning with the restoration of a single building, gradually gone to the space between the buildings, collections, textures, historic towns and today expanded to cultural look and town look (Jokilehto, 2007).

\section{Policies and General Directions of National Regenerating, Based on National Upper Documents}

Based on the strategic national document of restoration, improvement, modernization and empowerment of worn and inefficient context, according to Article 16 of the low of restoration, improvement and modernization of worn and inefficient context protection and with the aim of attracting cooperation and participation of all relevant devices in the process of areas and target neighborhoods sustainable regenerating, programs of restoration, improvement and modernization in order to protect the rights of citizenship, improving the quality of life, recovery of urban identity and domination of local governance and in direction of leadership, integrated management and create unity between all the relevant factors at the national and local regulations with the approach of Iranian-Islamic architecture urbanism, by the Ministry of Roads and Urban Development (Urban development and Regeneration organization Iran) and coordinated by the Ministry of Interior, coordinated by the Ministry of Cultural Heritage, Handicrafts and Tourism and the Supreme council of the provinces and according to Article 138 of the constitution has been approved by the Cabinet. This document is reference of common definitions, objectives, principles, strategies and policies of the Islamic Republic of Iran in urban restoration, improvement and modernization, and organizing informal settlements and empowerment of residents in two categories of preventive measures and measures related to the process of sustainable regenerating of areas and target neighborhoods of programs of restoration, improvement and modernization.

Whereas in different principles of the constitution and the document of "Vision of the Islamic Republic of Iran in 1404" social justice and fight against poverty and exclusion is a priority for the government, disesteem to the fate of the part of the residents in the cities of country that suffer from inadequate home, lack of services and urban infrastructure and the lack of healthy social environment, relative poverty and widespread unemployment, has no logical justification. That is why the Government of the Islamic Republic of Iran has taken long strides towards restoration, improvement and modernization. Experiencing more than a decade of continuous activities in this area shows that irrespective to the causes of the emergence and spreading of inchoate areas of urban and taking preventive measures, with emphasis on the purely physical actions in the field of restoration, improvement and renovation, cannot offer a solution to this complex issue. According to these documents, urban regeneration, including the process of comprehensive development in economic, social, environmental and somatic for raise of quality of life in target neighborhoods and areas has a link with the rest of the city. 
thus historical limit of cities are part or parts of cities which are reflector of cultural and historical values of city, and has shaped from interaction between humans and the peripheral environment in history and is distinguishable from other urban areas in terms of form features and constitutive structure (in the form of cultural and historical areas of a city determined by the Cultural Heritage, Handicrafts and Tourism).

\section{Regenerating Executive Strategies Based on National Documents}

In 2015 urban development and regeneration organization (holding), introduces urban regenerating comprehensive framework executive strategies as follows:

- $\quad$ Adjudicating citizenship rights in the text of the laws and national documents.

- $\quad$ Creation and raise of social capital in neighborhoods and targeted areas.

- $\quad$ Promotion of efficiency and productivity in the process of achievement to urban stable Regenerating.

- $\quad$ Capacity building of sociable in all actors of the Regenerating process of urban.

- Improve and promotion of condition of livelihoods and employment status of residents of the neighborhood and target areas based on actual demands and prioritize them with participatory planning approach.

- $\quad$ Promotion of the security of the residents of the target areas.

- $\quad$ Promotion of the residential satisfaction among residents of neighborhoods and target areas.

- $\quad$ stable conservation and restoration of cultural heritage, historical and cultural identity of cities

- $\quad$ Improve and promotion the phantasm of people from neighborhood and target areas.

- Development of the local society and promotion of sociable resiliency in the face of change.

- $\quad$ Protection environment and ecosystems.

- $\quad$ Promotion of the safety and sustainability of buildings against disasters and dangers in target areas and neighborhood.

- $\quad$ Promotion of the safety and sustainability of urban infrastructures and public space areas and target areas.

Promotion of the inborn and economic versatility in front of the disasters and changes in neighborhood and target areas.

- $\quad$ Promotion and expansion idea of urban resilience as sustainable lifestyle in the all Regenerating actions of the urban.

\section{Principles and Process of Urban Regeneration}

Part of the principles and process of the regenerating have been expressed in the section of the explanation of the concept, evolution trend and strategies related to regenerating, however, a number of domestic and foreign experts, including Pourahmad and et al (2011), Izadi (2006), Guzey (2006), expressly referring to a number of principles that is relevant to the 21 st century and time of the contemporary that the sum of their votes as follows:

1- Change and alterations of the economic: occupational opportunities, improve the distribution of wealth, fostering of the talents, reducing poverty and deprivation and providing facilities of the neighborhood and educational programs rather than alone somatic modernization and equilibrium and balance between public and private investment and voluntary. 
2- Change and alteration of the social: Improve the quality of life and social relations, reduce crime and emphasis on contribution of the communities in the works and the emergence of "community-based" approach, in the field of resolving of the exhaustion urban.

3- Change and alteration of the somatic: Solve problems related to somatic exhaustion with new lands and proportionate necessaries.

4- Governance: the reorganization of the mechanisms of decision-making through democratic consensus, enhance amount of the cooperation spaces and partnership, consider different expectations, emphasis on different regional cooperation, attention to interactions between organizations and institutions and their Interrelationships.

5- environment quality and sustainable development: introduction a more comprehensive idea of environment stability.

6- more emphasis on integrated approaches: somatic transformation with improving economic situation, somatic, social and environmental in one area with two main targets of economic efficiency and social justice.

7- $\quad$ More comprehensive form of strategy and action.

8- commitment and attention to the protection of the historic environment and affirmation to the importance of maintaining the spaces and original buildings.

9- $\quad$ More focus on culture, art and entertainment programs in the process of the renovation and regenerating of the urban.

\section{Basic Approaches of Urban Regeneration}

1- Creating industry approach: from the late 1970s and early 1980s, the somatic transformation of the devastated areas has found international trend, especially in partially destroyed industrial areas. Hall argues that globalization has led to a wave of de-industrialization in the cities that were host of older manufacture industries and less competitive power. Many from cities of the Western Europe and the United States of America have changed from the major centers of production to centers of consumption. Old heavy industries of the nineteenth century were destroyed and economic activities were transferred to the section services (Izadi 2006).

2- Environmental and somatic approach: After about three decades of complete focus on economic growth and appearance of the unpleasant consequences, this type of "development" on the body of the natural areas and urban settlements and threatens many of nonrenewable resources, after the late 1960s and early 1970s, attention to the environment and environmental issues, became essential and fundamental factor in urban planning. This juncture can be considered the beginning of serious attention to environmental issues. attention the concept of "sustainability" and the term of "sustainable development" in the 1980s and the publication of the Bruntland report in 1987, the environment income a basic topic in the topics "repair and regenerating city". Thus, environment to form fundamental and determinative debate in orientations and urban patterns and urban planning, was entered in the urbanization literature of this period. most important resultant success, accept necessity of doing work in accordance with the goals of environmental and somatic of sustainable development. thought "compact city" as a sustainable built form increasingly became popular among policymaker in European and national level. In general, takes place reinforcement and widespread support from the principles of sustainable development. strategies and plans related to "brownfield" is seen as help to compact and sustainable cities (Izadi 2006).

3- $\quad$ Approach of the development from within (Brownfield): report of government United Kingdom in 1997 shows that exhaustion of the central core of the cities, not only because of the economic situation of households and residents of these centers, But because of the critical of the entire of the economic mechanism inner sections of the cities. That is why comes the matter of "economic rehabilitation". In the United Kingdom 
and the United States, the importance of promoting from within, with the use of the term "Brownfield" to mean of the lands inside cities, have been proposed, that have already been the subject of constructions (Cowan, 2005). During this period, building on the lands of the "Brown field" as a solution for the contemporary growing problems of urban found new importance and prominence. Now the task of re-use and Improve of available resources are raised as the regenerating main task in throughout Europe (regenerating with focus on lands that have already been subject of the developments). Urban white report that prepared according to report of the Lord Rogers as "the urban renaissance" in England, the urban development new law that provided by the French government, programs of social cities in America and major cities in Netherlands, are obvious examples for these trends (McDonald, 2009).

4- Approach to service and performance: concurrent with the wane of traditional heavy industry, economic activities was transferred to the third section or the service section. This reconstruction of production, was released many resources in the destroying and empty cities. All areas have been left without their main source of employment and since the shops and services that were supported by the working population, were not able to survive, cause economic tensions and secondary economic wane. Thus, the reconstruction of old industrial areas became the center of regenerating activities. main part of the efforts of national and local building institutions were established with the aim of modernization of economic basement of the areas that had lost its function, and were focused on the aim of attracting internal investment. Citizens are encouraged to live and work in these areas with strategies such as: effective use of lands and buildings, supporting from development of new and available business and industry, creating an attractive environment and ensuring that housing and social facilities are available for the public. projects that run by large corporations of city (UDC), is defined as "superior project" and specifically "validated projects ", Which have insisted on the development of commercial real estate in old urban areas (Izadi 2007).

In United Kingdom, the national strategy of the Labour Party for renewal of neighborhoods include cases such as creation areas of educational user, and areas with sanitary user. This approach cause promotes commercial activities based on local communities, especially in the open market of the 1980s, some politicians reminisce the business areas as a way towards the future (w. caves, 2005).

5- Participatory and interactive approach: urbanism activities in the 1970s, has been more than kind of interactive way. In United Kingdom, the national strategy of the Labor Party for renewal of neighborhood include cases such as creation areas of educational user, and areas with sanitary user, and local strategic cooperation with emphasis on the necessity of public cooperations, planning of communities and ownership of the local people compared to change. This bottom-up approach, has promoted commercial and business activities and community growth based on local communities, Businesses that although not enough to restore the city, but can help creation immediate labor markets and small business culture, and pay the issue of reuse of the local workforce. The practical realization of empower the local community has led to dramatic changes through activity, organization, leadership and capacity building in the local community. Participatory and interactive approach, in addition to the above matter, it also includes participatory work of the several organizations. The objective of the creation of thought and collective action sometimes may lead to creation tension among institutions and organizations, but the government knows this aim as a consequence to reach onto holistically opinion and a new way in urban management and urban governance. participatory work of the several organizations to encourage participation and more involvement in the affairs of the city, is completed the electoral system (w. caves, 2005).

6- Cultural approach (culture-based Regenerating): After the 1980s, regenerating based on culture to form a huge wave, affected regenerating projects throughout Europe, and regenerating based on culture and use cultural capitals has raised as a successful option in the "restoration and rehabilitation and urban renewal" (Kearns and Philo, 1993). paying attention to the role of culture, the use of historical and cultural values as resources for development and also attention to spending leisure time, are the most important aspects of this tendency. Since policymakers and urban responsible authorities pay attention to "culture" as an instrument for urban regeneration, the importance of the quality of the historical environments increasingly been apparent as a part of innovations and initiatives of regenerating the city (Izadi Quoted from Pendel Beri, 2006). Cultural policies by creating jobs is related to running those jobs, advertise and promote of related holding stations such 
as bars, restaurants and etc, were considered as supplier economic benefits, so cultural interventions more than are product of the economic growth were its driving force (Izadi, 2007).

Movement of building museums in Europe, especially after the collapse of the Berlin Wall, became a dramatic movement to revive the collective memory and create fresh identity and " unique" for cities and urbanized, is One of the signs of use of the cultural instrument in the restoration and urban regenerating (Bianchini and Parkinson, 1993). In fact, the culture and cultural projects gradually found particularly important in urban regeneration, So that can be strengthened the regenerating with authentic artistic or cultural projects that have significant economic and social benefits (W.caves, 2005).

In fact, attention to the financial and economic interests in municipal projects, determined the route of the investment in the creation of cultural and artistic centers and leisure time, that from this way, in addition to return investment, due to the special attractions for the presence of people of practice areas, are quite impressed (Sohizadeh, Izadi. 2005).

The impression from concept of "culture" and entering it in the progress of urban development has been accompanied by a transformation and transmutation for decades. Between the 1940s and the 1960s, which know that course of "pre-electronic arts", art has been construes as a separate and even dissonant field from economy and generation: This is the same period that in the opinion of some, urban restoration still has constructive look, as well as affected from the global wars (Bianchini, 1999). During the 1970s and 1980s, the culture is a tool in the service of social and political goals, and do not have any role in the economic field, but since the 1990s, which some have called that "period of participation", culture used as a tool in the service of economic and somatic Regenerating of the town, and it is used in the urban policies (Kong, 2000).

At the beginning and during the 1940s to 1980s, the combination word "culture industry" was used to show sort of economy earning income through the promotion of "mono-cultural" or "mass culture ". This is the same concept to be challenged by intellectuals like Adorno, and finds a negative connotation (Adorno, 1991). in the next stage and then jump from this idea, were raised the concept of "cultural industries". At this cut and gradually, emerged a positive conception from intercourse culture with the economic development, and culture is considered as part of the planning strategy (McGuigan, 2012). hereinafter you can see performance more than ever of full range meaning and manifestations of culture in urban regenerating, as far as the report that was produced in England, Using the "creative industries" introduced as the most innovative use method from culture in urban Regenerating (DCMS, 2004). Thus, during the last three decades, done efforts to transform yesterday cities, with focus on manufacturing and industrial, to today cities, with focus on service activities, and with the many desire for use from culture as regenerating tool (Garcia, 2004). In a sense, from this point onward, regenerating put its main goal to converge the two streams of culture and economy (Bianchini, 1999), and this point is very important. henceforth, obtained different analysis about the role and importance of the cultural approach in urban regenerating, and can say "culture-based urban Regenerating" become an essential approach in the field of restoration and protection of urban (CCN, 2010).

\section{Cooperation Types of Culture in Urban Regeneration}

In a report that has been prepared by Evans and shaw in 2004, a policy document for the department of culture, media and sport of England from participation of cultural activities in Regenerating, and a variety of cultural participation have been stated in various fields of regenerating.

Table 1: participation of culture in various aspects of Regenerating, source: Evans and Shaw, 2004, quoted from Ayat, 2011.

\begin{tabular}{|l|ll|}
\hline & $\bullet$ & Reuse of vacant buildings \\
$\bullet$ & Raise the quality of the environment \\
\hline
\end{tabular}




\begin{tabular}{|c|c|}
\hline $\begin{array}{l}\text { Cultural participation in somatic } \\
\text { Regenerating }\end{array}$ & $\begin{array}{l}\text { Increased public use of space, that decrease the destruction } \\
\text { of public property and increase security. } \\
\text { feeling proud in one place } \\
\text { - Development a work Space / life and with mixed-use } \\
\text { (development / sustainable life, compact city, high density, little } \\
\text { environmental impacts, for example in traffic and transportation) } \\
\text { - } \quad \text { Employment artists in design groups } \\
\text { - } \quad \text { Merge of cultural ideas in future programs. }\end{array}$ \\
\hline $\begin{array}{l}\text { Cultural participation } \\
\text { in economic Regenerating }\end{array}$ & $\begin{array}{l}\text { - } \\
\text { internal investment (force of public-private sector) } \\
\text { and visitors } \\
\text { - } \quad \text { Spend more money (willingness to pay more) by residents } \\
\text { - } \quad \text { keep educated in place (artists / creatives) } \\
\text { - } \\
\text { diversity of the Jobs and workforce (skills level) } \\
\text { new entertainment centers } \\
\text { - } \quad \text { increasing participation of public and private section and } \\
\text { groups and voluntary associations } \\
\text { - } \quad \text { More participation in the sections of local culture (which } \\
\text { leads to increased willingness to pay) } \\
\text { - } \quad \text { rising cost of estate and real estate (residential and office) }\end{array}$ \\
\hline $\begin{array}{l}\text { Cultural participation in social } \\
\text { Regenerating }\end{array}$ & $\begin{array}{l}\text { Changing attitudes and perceptions of residents from } \\
\text { oneself accommodations } \\
\text { people } \\
\text { Reinforcement of the confidence and enthusiasm in the } \\
\text { needs. } \\
\text { - } \\
\text { Increase voluntary activities } \\
\text { networks that enable collective action. }\end{array}$ \\
\hline
\end{tabular}




\begin{tabular}{|l|ll|}
\hline & $\begin{array}{l}\bullet \\
\text { inhabitants }\end{array}$ \\
$\bullet$ & cooperation of public-private section and voluntary groups \\
$\bullet$ & access to high education level \\
\hline
\end{tabular}

\section{Case Studies}

In this section we will be discussed briefly about some domestic and foreign cases in regenerating background of cultural urban, and meanwhile It is important to note that outside projects most have been implemented due to more antiquity of urban regeneration concept in this countries, and their results is also clear. But because of the novelty of this concept in country, internal regenerating projects, remaining at the level of research projects or courses and a few of them were executed.

Table 2: evaluation cases study of cultural Regenerating, collected by the authors.

\begin{tabular}{|l|l|l|l|}
\hline \multicolumn{1}{|c|}{ City } & position & $\begin{array}{c}\text { motive element } \\
\text { of } \\
\text { cultural } \\
\text { Regenerating }\end{array}$ & \multicolumn{1}{|c|}{ General proceedings } \\
\hline Rasht & in process & $\begin{array}{l}\text { Cultural and } \\
\text { artistic branding }\end{array}$ & $\begin{array}{l}\text { Using the occasional and thematic festivals, create a jolly } \\
\text { urban spaces through the expansion of walkability and } \\
\text { build of unique street scenes using diverse vegetation and } \\
\text { small business users that operate in more hours a day, and } \\
\text { eliminating empty spaces from main sights of the streets } \\
\text { and squares. city of Rasht plans achieve to develop and } \\
\text { improve tourism in national and international level } \\
\text { through cultural and social branding, And with this way } \\
\text { facilitate to achieve to the cultural regeneration (The } \\
\text { Improvement And Modernization of Municipal Rash) }\end{array}$ \\
\hline $\begin{array}{l}\text { Qazvin } \\
\text { chistorical } \\
\text { context) }\end{array}$ & $\begin{array}{l}\text { Research } \\
\text { project }\end{array}$ & Tourism & $\begin{array}{l}\text { City of Qazvin want to achieve cultural Regenerating } \\
\text { with protection and restoring cultural events such as } \\
\text { celebrations and historical traditions of the city of Qazvin } \\
\text { (Panjah Beadr ceremony, Fandog Chini celebrating and } \\
\text { etc.) and protection of historic buildings and spaces with } \\
\text { restoring and inject user to them, and also creation } \\
\text { buildings with new use and attractive of population such } \\
\text { as handicrafts stores, libraries, theaters, concert halls, } \\
\text { cultural center, exhibitions and etc, (Aminzadeh and } \\
\text { Dadras, 2013). }\end{array}$ \\
\hline $\begin{array}{l}\text { Shiraz } \\
\text { complex } \\
\text { located in } \\
\text { historical } \\
\text { context) }\end{array}$ & $\begin{array}{l}\text { Research } \\
\text { project }\end{array}$ & Cultural sights & $\begin{array}{l}\text { city of Shiraz has tried to achieve to cultural regeneration } \\
\text { by restoring the role of collective vital, memory } \\
\text { construction and strengthening of collective memories in } \\
\text { the historical memory of the city and remove the } \\
\text { incompatible functions from the sides of the collection, } \\
\text { and also with injection diverse uses and population } \\
\text { attractive, which represents the city's identity, and }\end{array}$ \\
\hline
\end{tabular}




\begin{tabular}{|c|c|c|c|}
\hline & & & $\begin{array}{l}\text { reinforcement of symbols and elements of historical } \\
\text { valuable (Pourahmad and Dehgani, 2012). }\end{array}$ \\
\hline $\begin{array}{l}\text { Mashhad } \\
\text { (Historical } \\
\text { context) }\end{array}$ & $\begin{array}{l}\text { Research } \\
\text { project }\end{array}$ & $\begin{array}{ll}\text { Imam } & \text { Reza } \\
\text { shrine }\end{array}$ & $\begin{array}{l}\text { use and reinforcement of religious element due to } \\
\text { existence the holy shrine of Imam Reza and recourse } \\
\text { diverse individuals from around the world to the shrine } \\
\text { which is located in the central parts and historical context } \\
\text { of the Mashhad and Implementation of creativity through } \\
\text { increased interactions and spatial interactions with help } \\
\text { other elements of historic valuable context and repair and } \\
\text { restoration of them and also creates competition among } \\
\text { the center of the town with other sections as a place to } \\
\text { attract new capitals with utilization from applications of } \\
\text { attractive population such as small commercial } \\
\text { applications and cultural users such as theaters, picture } \\
\text { galleries, galleries, cultural venues and etc, along with use } \\
\text { from environmental arts can lead to regenerating of the } \\
\text { historic and old center of Mashhad through cultural } \\
\text { factors (Safdari and et al 2015). }\end{array}$ \\
\hline Barcelona & performed & City of parks & $\begin{array}{l}\text { Temporary allocation of some not built lands into the city } \\
\text { to parks and green spaces to create a jolly urban with } \\
\text { social values, cultural traditions and local identity that in } \\
\text { addition to preventing from leave the area by residents, } \\
\text { protection from them for future construction, And this } \\
\text { matter cause presence and activity of artists and architects } \\
\text { for use of their creativity for create new social with } \\
\text { protection from last historical monuments of context } \\
\text { (Lndry, 1996). }\end{array}$ \\
\hline $\begin{array}{l}\text { Hay- on- } \\
\text { Way }\end{array}$ & performed & City of Book & $\begin{array}{l}\text { in start, Was known as largest city of on- sale second- } \\
\text { hand book in world, which gradually increase in } \\
\text { employed people in this profession, improved the city's } \\
\text { economic situation and caused cultural regeneration in } \\
\text { this city with relative increase of bars, restaurants, } \\
\text { cinemas and theaters, exhibition spaces, resorts and } \\
\text { hotels, and etc (Landry, 1996). }\end{array}$ \\
\hline Maidstone & performed & City of Light & $\begin{array}{l}\text { Use of diverse and palatial lighting as a factor for } \\
\text { distinguish of city compared to peripheral cities, and } \\
\text { increase in tourism that began with the idea of Christmas } \\
\text { lighting and expanded. this element in addition was an } \\
\text { attractive factor, frame the art of other architects, } \\
\text { sculptors, painters and other artists that present their art in } \\
\text { the streets and squares, And gave to them a better } \\
\text { manifestation and thus the spread of street life through } \\
\text { increased cafes, restaurants, street theaters and etc caused } \\
\text { cultural regenerating in this city (Landry, 1996). }\end{array}$ \\
\hline Penzance & performed & $\begin{array}{l}\text { city of forgotten } \\
\text { traditional } \\
\text { ceremonies and } \\
\text { customs of } \\
\text { Scottish }\end{array}$ & $\begin{array}{l}\text { Use from commemoration of historical events in start } \\
\text { began with interest of one of the schools in the city to } \\
\text { eighteenth century Scotland and writing script and play } \\
\text { theater based on one of this events that called " Mazey } \\
\text { Day", that was supposed to that same time is regenerate } \\
\text { the city with promote the fishing industry and improve the }\end{array}$ \\
\hline
\end{tabular}




\begin{tabular}{|l|l|l|}
\hline & $\begin{array}{l}\text { retails and create "Pirate Day". But in the end, which won } \\
\text { this theater and " Mazey Day" and this day gradually } \\
\text { expanded and convert along "Golwan's holiday" a } \\
\text { ceremony for the whole year, that this matter in addition } \\
\text { to affluence many other activities such as exhibitions, and } \\
\text { clothing, bars and etc. which increased sources of income } \\
\text { of the city through tourism, also cause support and } \\
\text { strengthen the identity and forgotten culture of the } \\
\text { Scottish in the minds of citizens and thus the city } \\
\text { achieved to cultural regenerating (Landry, 1996). }\end{array}$ \\
\hline
\end{tabular}

According to the clarification and comparison samples of this table, the factors that can facilitate cultural regeneration or advent of it, are many and varied, that in this matter depends on origin of renewal, possibilities and available potential of the region, public participation, help of authorities, And urban management and eventually better correct and planning, with adequate human and financial resources. also with reflecting on the above table, we can see that sometimes only with factors like books and reading, or different lighting have as the initiator of cultural Regenerating of the city. And sometime historical identity potentials in a city are underlying cultural regenerating, such as Imam Reza Holy Shrine, Or specific days and aboriginal and traditional traditions (Mayez's day and Golwan's celebration). According to foreign samples shows that knowledge and implies recognizing and taking advantage of the potentials and motive factors in these countries are more diversified, Unfortunately, due to freshness meanings of regenerating in the country, assessment of samples shows that there is a historicist look to cultural regenerating.

\section{RESULT}

City is a live body that to be exhaustion over time and result of several factors, according to concept of decrease of exhaustion effect and reuse of buildings and spaces of city started restoration in different forms from course of Hvsman, And especially intensifies after World War II and the urgent need to rebuild of the damaged parts from war, and after 1980s and formation of word of regenerating, in the first decade of the 21st century, according to concepts of sustainability to became urban regeneration, until is responder the needs of the present era. also there are treaties and written documents for explaining and describing of the priorities for variety of species of restoration in each period, One of the most important of them in the country is strategic national document of regeneration, restoration, improvement, modernization and empowerment of distressed and inefficient areas of urban, that major goals of this document is retrieved from perspective of the Islamic Republic of Iran in 1404, And also urban development and Regenerating organization is provided administrative strategies in this direction. different approaches and attitudes are formed in accordance with the progress periods of regenerating due to importance of an issue in a particular period, that these approaches are include: creating industry approach, somatic and environmental approach, development from within approach, service and performance approach, interactive and participatory approach and eventually cultural approach that has also been studied approach in this research. It is worth noting that after the evolution of reformation of culture in time length and its importance in different periods of time, according to governing different conditions, use of the creative industries, is known most innovative method of use of culture in urban regenerating. also exploitation from this concept can be expressed in economic and social form, that to achieve to urban regenerating with culture-based approach must pursue specific strategies in each of these dimensions, today Around the world projects of the urban regenerating is running with an emphasis on cultural approach in many different scales, that each of them are formed on the basis of knowledge about the natural characteristics, somatic, regional, cultural, social, economic and etc. But due to this concept is new in the country, renewal projects especially cultural regeneration is proposed in research projects and university-level and only a few of them have been implemented. In the end, it was hoped that due to the more fixation of concept of renewal, and in particular the cultural regeneration over time, and achieve to successful with attention to the enormous potential of different regions of country and in terms of cultural diversity, continental, and somatic and etc. 


\section{REFERENCES}

Adorno, Theodor W. (1991), The Culture Industry: Selected essays on mass culture, Routledge, London and NewYork.

Aminzadeh Behnaz, Dadras Raheleh (2013), Culture-led Regeneration in Historical Texture of Qazvin with Emphasis on Urban Tourism, Journal of Iranian Architecture Studies, Volume 1, Issue 2, fall and winter 2013, pages $99-108$

Ashworth, G.J. (1991), Heritage planning. Conservation as the management of urban change, Geo pers.

Ayat Narges Sadat (2009). Urban Regeneration in Old Texture of Semnan Town, MSc Thesis, University of Tehran.

Bianchini, F. \& Parkinson, M.( 1993). Cultural policy and Urban Regeneration: The Western European Experience, , Manchester University Press, Manchester.

Comprehensive Framework of Sustainable Urban Regeneration, Urban Development and Revitalization Organization of Iran, volume 1, August 2015.

Cowan, Robert.(2005). «The Dicthonary of Urbanism», Great Britain: Streetwise press.

Creative City Network (CCN) (2010), Cultural Planning Toolkit, A Partnership between 2010 Legacies Now and Creative City Network of Canada, Vancouver, Canada.

DCMS (Department for Culture Media and Sport) (2004), The Contribution of Culture to Regeneration in The UK, London Metropolitan University, London.

English Heritage (2008), Conservation Prin ciples: Policies and Guidance for the Sustainable Management of the Historic Environment, English Heritage, London.

Garcia, B. (2004), Cultural Policy and Urban Regeneration in Western European Cities: Lessons from Experience, Prospects for the Future, Local Economy, Vol. 19, No. 4, pp. 312-326, November.

Habibi Qumars, Pourahmad Ahmad, Meshkini Aboulfazl (2008), Urban Worn-out Texture Improvement and Renovation, University of Kordestan and Urban Development and Revitalization Organization press, volume 1.

Habibi Seyyed Mohsen, Maqsudi Maliheh (2008). Urban Restoration, Tehran University press, $3^{\text {rd }}$ edition. Tehran.

Hanachi Pirouz et al. (2008). Conservation and Development in Iran (The Analysis Restoration Experiences in Valuable Textures of Iran Historical Cities). Journal of Honar-haye Ziba, issue 32, winter of 2008, pages 51-60.

Hanachi Pirouz, Fadayinezhad Somayyeh (2012), Integrated Conservation and Regeneration Conceptual Framework Design in Cultural- Historical Texture, Journal of Honar-haye Ziba, issue 46, summer of 2011, pages 15-26.

Izadi, M.S (2006). As on citycenter . Regenertion: A comparative analysis of two different approachestotherevitalizationofhistoriccitycentersinIran. Newcastle University.

Jokilehto, J. (1998), Organization, charters and world movement- an overview, in Warren, J., Worthington, J. and Taylor, S.(eds) Context: new building in historic settings. Architectural Press: Boston, pp. 40-50.

Jokilehto, J. (2007), International charters on urban conservation: some thoughts on the principles expressed in current international doctrine. City \& Time 3 (3): 2.

Kearns, G. \& Philo, C.(1993). Selling Places: The past as Cultural Capital Past and Present, Oxford: Pergamon Press.

Kong, L. (2000), Culture, Economy, Policy: Trends and Developments, Geoforum, Special issue on Cultural Industries and Cultural Policies, 31(4), pp. 385-390.

Landry, C. (1996). The art of regeneration: Urban renewal through cultural activity. Stroud: Comedia.

Larkham, P. J. (1999), Preservation, Conservation and Heritage: Developing Concepts and Applications. IN Cullingworth, J. B. (Ed.) British planning: 50 years of urban and regional policy. New Brunswick, N.J., Athlone Press.

Lotfi Sahand (2009), Urban Regeneration and Conservation, Concepts and Conditions, Phd thesis for Urbanism, Urbanism Faculty, Department of Fine Art (Honarhaye Ziba), University of Tehran.

Lotfi Sahand (2012), Culture-led Urban Regeneration: Contemplation on Cultural Motifs and Regeneration act, Department of Fine art (Honarhaye Ziba), issue 45, spring of 2012, pages 47-60.

McDonald, S.; Malys, N.; Maliené, V.(2009)Urban regeneration for sustainable communities: A case study, Technological and Economic Development of Economy 15(1): 49-59.

McGuigan, J. (2010), Cultural Analysis, SAGE Publications Inc. 
National Strategic Document of Restoration, Improvement, Renovation and Rehabilitation Urban Worn-out and Inefficient Textures, summer 2014.

Ozlem, G.(2009). Urban Regeneration and increased comparative power: Ankara in an era of globalization. Cities Vol.26.P:27-37.

Pendlebury, J. (2005), 'The Modern Historic City: Evolving Ideas in Mid-20th-century Britain', Journal of Urban Design, 10, (2), pp. 253-273.

Pendlebury, J. (2009), Conservation in the age of consensus,USA and Canada: Rutledge.

Pourahmad Ahmad et al. (2011). The Evolution Process of Urban Regeneration Concept as a Novel Approach in Urban Worn-out Texture, Journal of Studies on Iranian-Islamic City, Volume 1, Issue 1, fall 2011, pages 72-93.

Pourja'far Mohammadreza, Dehqani Fahimeh (2012). The Role of Cultural Sights Regeneration on Citizens' Lives Quality Improvement, Case Study: Shiraz Zandieh Complex, Journal of Naqshe Jahan, Volume 1, Issue 1, fall 2012, pages 81-94.

Roberts, P. 2000. The evolution, definition and purpose of urban regeneration, in P.Roberts and H. Syke(eds.). Urban Regeneration, A Handbook. British Urban Regeneration Association, SAGE Publications,London, 936.

Roberts, P. \& Sykes, H. (2000). Urban Regeneration: Handbook, Londan. Sage Publications.

Safdari Sima, PourJa'far Mohammadreza, Ranjbar Ehsan (2015), Culture-led Regeneration as an Underlie of Cultural Iinteractions Improvement, Case study: Mashhad town Historical Texture, Haftshahr Journal, volume 4, issue 47 and 48, winter of 2015, pages 25-39.

Sohizadeh Mahshid, Izadi Mohammad Saeed (2005), Conservation and Development: Two Complementary or Inconsistent Approaches?, Abadi Journal, volume 14, issue 43, summer of 2007 12-21.

W.Caves, R.( 2005). Encyclopedia of the city. Newyork: Routledge. 